\section{Determination of the Absolute Configuration of Synerazol}

\author{
YASUhiro IgARAShi*, YUKIhIRO Yabuta and \\ TAMOTSU FURUMAI
}

Biotechnology Research Center, Toyama Prefectural University 5180 Kurokawa, Kosugi, Imizu, Toyama 939-0398, Japan

(Received for publication April 8, 2004)

Synerazol (1) was originally isolated as an antifungal antibiotic from Aspergillus fumigatus ${ }^{1}$. 1 possesses an epoxy functionality instead of the 1,2-dihydroxyl group in pseurotin A (2), the first identified member of this class of secondary metabolites. While the absolute configuration of 2 was determined by X-ray diffraction ${ }^{2}$, the stereochemistry of 1 remains to be solved. We recently found that fluorinated analogs of synerazol, produced by the precursor-directed biosynthesis using fluorophenylalanines, show potent antiangiogenic activity ${ }^{3)}$. Since pseurotin analogs do not show such activities, the epoxy moiety is considered important.

A. fumigatus TP-F0182 produces both $\mathbf{1}$ and $\mathbf{2}$ in a liquid fermentation $^{3)}$. 1 and $\mathbf{2}$ were confirmed to be synerazol and pseurotin A, respectively, by comparing the UV, optical rotation, FAB-MS and ${ }^{1} \mathrm{H}$ and ${ }^{13} \mathrm{C}$ NMR data ${ }^{1,2,4)} . \mathbf{1}$ is liable to react with a water molecule in acidic and neutral aqueous medium to yield a diol compound whose chromatographic behavior is identical with that of $\mathbf{2}$. It was thus assumed that 1 and $\mathbf{2}$ are derived from the same biosynthetic precursor and therefore have a common stereochemical character. We herein report the determination of the absolute configuration of $\mathbf{1}$ in two parts: (1) determination of the stereochemistry in the right half of the molecule by spectroscopic comparison with 2; (2) determination of the absolute configuration of the epoxy moiety by using the modified Mosher's MTPA method ${ }^{5)}$.

Based on the assumption, the epoxy ring of 1 was cleaved in aqueous tetrahydrofuran in the presence of $p$ toluenesulfonic acid ( $p$-TsOH). ${ }^{1} \mathrm{H}$ and ${ }^{13} \mathrm{C}$ NMR spectra of the hydrolysate $\mathbf{3}$ were in good accordance with those of $\mathbf{2}$ and, in the NMR spectrum of the equimolar mixutre of $\mathbf{2}$ and 3, splittings of proton and carbon signals due to the heterologous mixture were not observed. Therefore the relative configuration of $\mathbf{3}$ is identical with $\mathbf{2}$ and thus the configuration of the spiro ring system of synerazol is identical with that of $\mathbf{2}$. Next, the optical rotations of $\mathbf{2}$ and 3 were compared. The $[\alpha]_{\mathrm{D}}$ value of $\mathbf{3}$ was +85.3 (c 0.28, $\left.\mathrm{CHCl}_{3}\right)$ whereas that of 2 was $+87.2\left(c 0.47, \mathrm{CHCl}_{3}\right.$ ). Hence the absolute configuration of $\mathbf{1}$ was established except for its epoxide moiety.

To determine the absolute configuration at $\mathrm{C}-10$ and C11, the epoxy ring was opened and the modified Mosher's method was applied to the generated secondary alcohol. Prior to the epoxide cleavage, 9-OH was protected with acetyl group by the treatment of $\mathbf{1}$ with acetic anhydride in pyridine, which was associated with the acetylation of 7 . $\mathrm{NH}$ group to give 4. To circumvent the generation of two secondary hydroxyl groups, methanol was used for the epoxy opening. 4 was reacted with methanol in the presence of $p$-TsOH to give 5. The cleavage of the epoxy ring exclusively occurred at $\mathrm{C}-11$, which was confirmed by the detection of ${ }^{1} \mathrm{H}-{ }^{1} \mathrm{H}$ couplings between $10-\mathrm{OH}(\mathrm{d}$, $\left.J_{10-\mathrm{OH}, 10}=6.3 \mathrm{~Hz}\right), \quad 10-\mathrm{H} \quad\left(\mathrm{t}, J_{10,10-\mathrm{OH}} \sim J_{10,11}=6.1 \mathrm{~Hz}\right)$ and $11-\mathrm{H}$ (ddd, $J_{10.11}=6.1 \mathrm{~Hz}$ ). To determine the absolute configuration at C-10, $(R)$ - and (S)-MTPA esters (6a and 6b) were prepared from 5 and their ${ }^{1} \mathrm{H}$ NMR chemical shifts were compared. The negative $\Delta \delta$ values were arranged on the left side of the MTPA plane and the positive values except for 9-OAc and $19-\mathrm{H}$ protons could be seen on the right side of the MTPA plane, indicating 10-S configuration (Fig. 3). The absolute configuration of

Fig. 1. Structures of synerazol and pseurotin A.
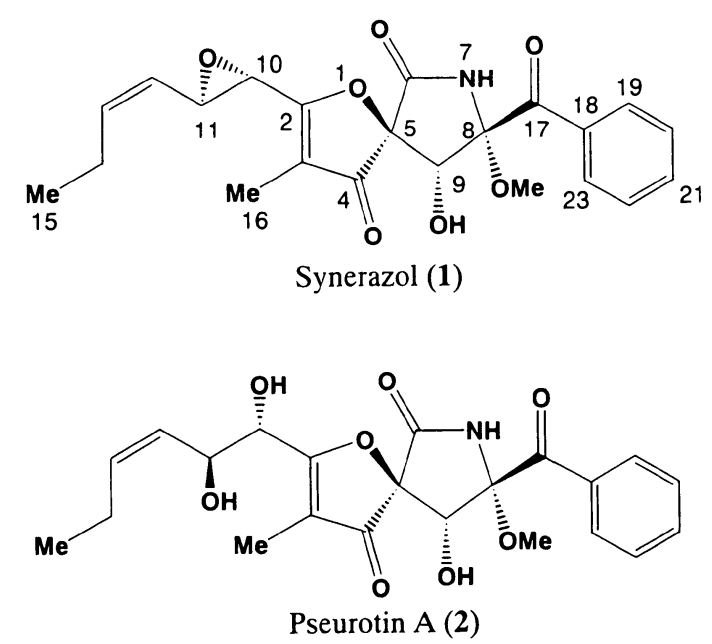

\footnotetext{
* Corresponding author: yas@pu-toyama.ac.jp
} 
Fig. 2. Acid-catalyzed epoxide opening and determination of the absolute configuration of $\mathbf{1}$.

(i) Determination of the absolute configuration of the spiro ring system

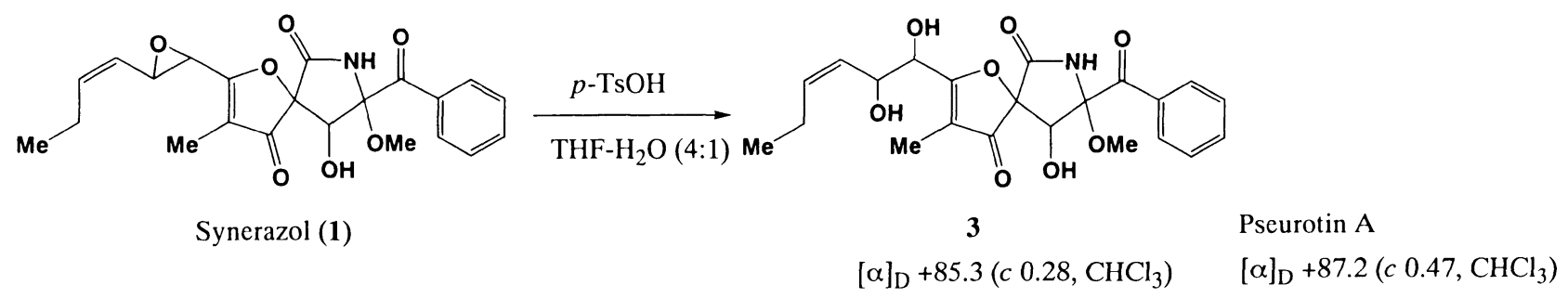

(ii) Determination of the absolute configuration of the epoxide

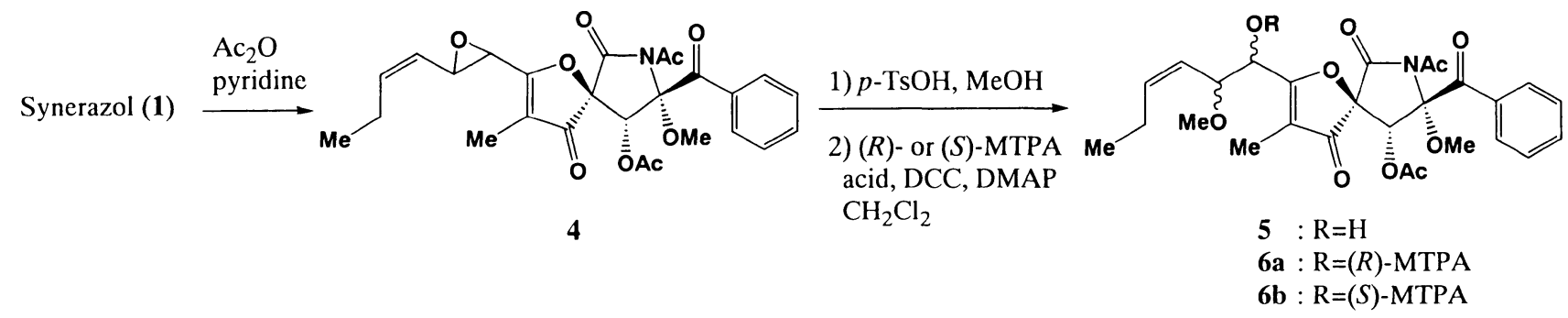

Fig. 3. Application of the modified Mosher's method.

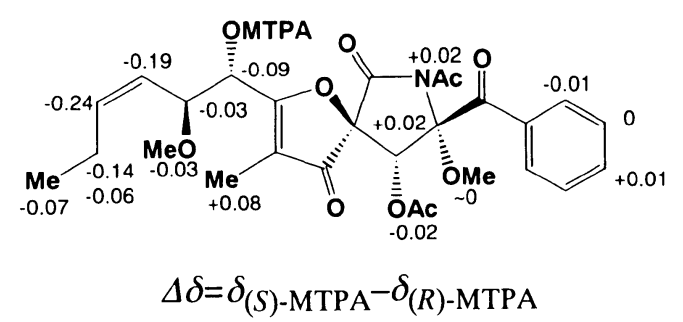

synerazol was hence defined as $\mathbf{1}$ in Fig. 1.

\section{Experimental}

\section{General}

All NMR experiments were performed on a JEOL JNMLA400 NMR spectrometer in $\mathrm{CDCl}_{3}$ with TMS as an internal standard. The MS spectra were measured on a JEOL JMS AX500 spectrometer. Optical rotations were measured on a Horiba SEPA-300 polarimeter.

\section{Hydrolysis of Synerazol}

Synerazol $\left(8.0 \mathrm{mg}, \quad 19 \mu \mathrm{mol}, \quad[\alpha]_{\mathrm{D}}^{18}+21.6\right.$ (c) 0.46 , $\left.\mathrm{CHCl}_{3}\right)$ ) was dissolved in a solution of $p$-toluenesulfonic acid monohydrate $(5 \mathrm{mg}, 26 \mu \mathrm{mol})$ in $\mathrm{THF}-\mathrm{H}_{2} \mathrm{O}(4: 1$, $5 \mathrm{ml}$ ), and the mixture was allowed to stand for 24 hours at $30^{\circ} \mathrm{C}$. Then, the reaction mixture was diluted with water, extracted with EtOAc, washed with saturated $\mathrm{NaHCO}_{3}$ solution, dried over $\mathrm{MgSO}_{4}$, filtered and concentrated in vacuo. The residue was purified by preparative TLC [ $n$ hexane/EtOAc ( $1: 2)$ ] to give 3 ( $4.4 \mathrm{mg}, 54 \%$ yield).

$$
\text { 3: }[\alpha]_{\mathrm{D}}^{24}+85.3\left(c 0.28, \mathrm{CHCl}_{3}\right) \text {. }
$$

Pseurotin A (2): $[\alpha]_{\mathrm{D}}^{24}+87.2\left(c 0.47, \mathrm{CHCl}_{3}\right),[\alpha]_{\mathrm{D}}^{26}-3.0$ (c $0.5, \mathrm{MeOH})$.

\section{Acetylation of Synerazol}

To a solution of synerazol $(100 \mathrm{mg}, 0.24 \mathrm{mmol})$ in dry pyridine $(2 \mathrm{ml})$ was added acetic anhydride $(1 \mathrm{ml})$ at room temperature. After 18 hours, the reaction mixture was poured onto ice-water and extracted with EtOAc. The organic layer was successively washed with saturated $\mathrm{CuSO}_{4}$ solution, saturated $\mathrm{NaHCO}_{3}$ solution and brine, dried over $\mathrm{MgSO}_{4}$, filtered and concentrated in vacuo. The residue was chromatographed on a column of silica gel [ $n$-hexane/EtOAc $(10: 1 \sim 4: 1)]$ to give $7,9-N, O$-diacetylsynerazol 4 (72 mg, 60\%). 
4: $[\alpha]_{\mathrm{D}}^{26}+1.8\left(c 1.0, \mathrm{CHCl}_{3}\right) ;{ }^{1} \mathrm{H}$ NMR: $\delta 1.09(3 \mathrm{H}, \mathrm{t}$, $J=7.6 \mathrm{~Hz}, 15-\mathrm{H}), 1.85(3 \mathrm{H}, \mathrm{s}, 16-\mathrm{H}), 2.09(3 \mathrm{H}, \mathrm{s}, 9-$ $\left.\mathrm{OCOCH}_{3}\right), 2.30(1 \mathrm{H}$, ddqd, $J=1.4,7.6,7.6$ and $14.6 \mathrm{~Hz}$, $14-\mathrm{H}), 2.36(1 \mathrm{H}$, ddqd, $J=1.2,7.6,7.6$ and $14.6 \mathrm{~Hz}, 14-\mathrm{H})$, $2.56\left(3 \mathrm{H}, \mathrm{s}, 7-\mathrm{NCOCH}_{3}\right), 3.63\left(3 \mathrm{H}, \mathrm{s}, 8-\mathrm{OCH}_{3}\right), 3.79(1 \mathrm{H}$, d, $J=2.0 \mathrm{~Hz}, 10-\mathrm{H}), 4.17(1 \mathrm{H}, \mathrm{dd}, J=1.7$ and $8.6 \mathrm{~Hz}, 11-\mathrm{H})$, $5.11(1 \mathrm{H}$, tdd, $J=1.5,9.0$ and $10.5 \mathrm{~Hz}, 12-\mathrm{H}), 5.59(1 \mathrm{H}, \mathrm{s}$, $9-\mathrm{H}), 5.90(1 \mathrm{H}$, td, $J=7.6$ and $11.0 \mathrm{~Hz}, 13-\mathrm{H}), 7.40(2 \mathrm{H}, \mathrm{t}$, $J=8.1 \mathrm{~Hz}, 20$ and $22-\mathrm{H}), 7.51(1 \mathrm{H}, \mathrm{tt}, J=1.2$ and $7.3 \mathrm{~Hz}$, $21-\mathrm{H}), 8.01(2 \mathrm{H}, \mathrm{dd}, J=1.2$ and $6.8 \mathrm{~Hz}, 19$ and $23-\mathrm{H}) ;{ }^{13} \mathrm{C}$ NMR: $\delta 5.19(16-\mathrm{C}), 14.05(15-\mathrm{C}), 20.18\left(9-\mathrm{OCOCH}_{3}\right)$, 21.32 (14-C), $25.38\left(7-\mathrm{NCOCH}_{3}\right), 52.53$ (10-C), 53.82 $\left(8-\mathrm{OCH}_{3}\right), 55.05$ (11-C), 75.01 (9-C), 88.61 (5-C), 93.75 (8-C), 113.91 (3-C), 123.48 (12-C), 127.74 (20 and 22-C), 130.44 (19 and 23-C), 132.51 (21-C), 135.78 (18-C), 141.54 (13-C), $165.10(6-\mathrm{C}), 169.05\left(9-\mathrm{OCOCH}_{3}\right), 170.32$ (7- $\left.\mathrm{NCOCH}_{3}\right), 181.36$ (2-C), 194.94 (4-C), 197.53 (17-C); EI-MS $m / z 497 \mathrm{M}^{+}$; HREI-MS $m / z 497.1718 \mathrm{M}^{+}$(calcd $m / z 497.1686$ for $\mathrm{C}_{26} \mathrm{H}_{27} \mathrm{O}_{9} \mathrm{~N}$ ).

Acid-catalyzed Epoxide Opening with Methanol of 7,9$N, O$-Diacetylsynerazol (4)

7,9-N,O-Diacetylsynerazol $4(70 \mathrm{mg}, 0.14 \mathrm{mmol})$ was dissolved in a solution of $p$-toluenesulfonic acid monohydrate $(6 \mathrm{mg}, 0.003 \mathrm{mmol})$ in $\mathrm{MeOH}(6 \mathrm{ml})$ and the solution was kept at $4^{\circ} \mathrm{C}$ for 18 hours. The reaction mixture was diluted with water, extracted with EtOAc, washed with saturated $\mathrm{NaHCO}_{3}$ solution and brine, dried over $\mathrm{MgSO}_{4}$, filtered and concentrated in vacuo. The residue was chromatographed on a column of silica gel ( $n$ hexane/EtOAc $10: 1 \sim 3: 1)$ to give 7,9- $\mathrm{N}, \mathrm{O}$-diacetyl-11-Omethylpseurotin A 5 (34 mg, 45\%).

5: $[\alpha]_{\mathrm{D}}^{26}-52.9\left(c 0.49, \mathrm{CHCl}_{3}\right) ;{ }^{1} \mathrm{H}$ NMR: $\delta 1.01(3 \mathrm{H}, \mathrm{t}$, $J=7.6 \mathrm{~Hz}, 15-\mathrm{H}), 1.75(3 \mathrm{H}, \mathrm{s}, 16-\mathrm{H}), 2.08(3 \mathrm{H}, \mathrm{s}, 9-$ $\left.\mathrm{OCOCH}_{3}\right), 2.08(1 \mathrm{H}$, ddqd, $J=1.5,7.3,7.6$ and $14.6 \mathrm{~Hz}$, $14-\mathrm{H}), 2.22(1 \mathrm{H}$, ddqd, $J=1.3,7.3,7.6$ and $14.6 \mathrm{~Hz}, 14-\mathrm{H})$, $2.57\left(3 \mathrm{H}, \mathrm{s}, 7-\mathrm{NCOCH}_{3}\right), 2.78(1 \mathrm{H}, \mathrm{d}, J=6.3 \mathrm{~Hz}, 10-\mathrm{OH})$, $3.35\left(3 \mathrm{H}, \mathrm{s}, 11-\mathrm{OCH}_{3}\right), 3.63\left(3 \mathrm{H}, \mathrm{s}, 8-\mathrm{OCH}_{3}\right), 4.36(1 \mathrm{H}$, ddd, $J=0.8,6.1$ and $9.5 \mathrm{~Hz}, 11-\mathrm{H}), 4.69(1 \mathrm{H}, \mathrm{t}, J=6.1 \mathrm{~Hz}$, $10-\mathrm{H}), 5.33(1 \mathrm{H}$, tdd, $J=1.7,9.5$ and $11.0 \mathrm{~Hz}, 12-\mathrm{H}), 5.62$ $(1 \mathrm{H}, \mathrm{s}, 9-\mathrm{H}), 5.85(1 \mathrm{H}, \mathrm{td}, J=7.7$ and $11.0 \mathrm{~Hz}, 13-\mathrm{H}), 7.40$ $(2 \mathrm{H}, \mathrm{t}, J=7.6 \mathrm{~Hz}, 20$ and $22-\mathrm{H}), 7.52(1 \mathrm{H}, \mathrm{tt}, J=1.2$ and $7.3 \mathrm{~Hz}, 21-\mathrm{H}), 8.01(2 \mathrm{H}, \mathrm{dd}, J=1.5$ and $7.0 \mathrm{~Hz}, 19$ and 23-H); ${ }^{13} \mathrm{C}$ NMR: $\delta 5.69$ (16-C), $14.23(15-\mathrm{C}), 20.18(9-$ $\left.\mathrm{OCOCH}_{3}\right), 21.29$ (14-C), $25.40\left(7-\mathrm{NCOCH}_{3}\right), 53.84$ (8$\left.\mathrm{OCH}_{3}\right), 56.57\left(11-\mathrm{OCH}_{3}\right), 70.04(10-\mathrm{C}), 75.13(9-\mathrm{C}), 77.11$ (11-C), 88.32 (5-C), 93.63 (8-C), 112.88 (3-C), 124.13 (12C), 127.75 (20 and 22-C), 130.42 (19 and 23-C), 132.49 (21-C), 135.91 (18-C), 139.95 (13-C), 165.05 (6-C), 169.19 $\left(9-\mathrm{OCOCH}_{3}\right), 170.49\left(7-\mathrm{NCOCH}_{3}\right), 185.27$ (2-C), 195.68
(4-C), 197.83 (17-C); FAB-MS m/z $530(\mathrm{M}+\mathrm{H})^{+}, 552$ $(\mathrm{M}+\mathrm{Na})^{+}$; HRFAB-MS $\mathrm{m} / \mathrm{z} 530.2019(\mathrm{M}+\mathrm{H})^{+}(\mathrm{calcd} \mathrm{m} / \mathrm{z}$ 530.2026 for $\mathrm{C}_{27} \mathrm{H}_{32} \mathrm{O}_{10} \mathrm{~N}$ ).

$(R)$ - and $(S)$ - $\alpha$-Methoxy- $\alpha$-(trifluoromethyl)phenylacetyl (MTPA) Esters of Compound 5

A solution of $(R)$-MTPA acid $(20.4 \mathrm{mg}, 87 \mu \mathrm{mol})$, dicyclohexylcarbodiimide $(26 \mathrm{mg}, 126 \mu \mathrm{mol})$ and 4 dimethylaminopyridine $(10.6 \mathrm{mg}, 87 \mu \mathrm{mol})$ in dry $\mathrm{CH}_{2} \mathrm{Cl}_{2}$ $(2 \mathrm{ml})$ was added to $5(15 \mathrm{mg}, 28 \mu \mathrm{mol})$. The mixture was allowed to stand for 18 hours at room temperature. Then, the reaction mixture was loaded on a column of silica gel and chromatographed with the eluent of $n$-hexane/EtOAc $(10: 1 \sim 5: 1)$ to afford $8.9 \mathrm{mg}$ of $(R)$-MTPA ester $6 \mathbf{6}$. In the same manner as described above, $5(15 \mathrm{mg})$ was reacted with (S)-MTPA acid (20.4 mg) to give $7.6 \mathrm{mg}$ of (S)-MTPA ester $\mathbf{6 b}$.

6a: 'H NMR: $\delta 0.924(3 \mathrm{H}, \mathrm{t}, J=7.6 \mathrm{~Hz}, 15-\mathrm{H}), 1.762$ $(3 \mathrm{H}, \mathrm{s}, 16-\mathrm{H}), 2.041\left(3 \mathrm{H}, \mathrm{s}, 9-\mathrm{OCOCH}_{3}\right), 1.933(1 \mathrm{H}, \mathrm{ddqd}$, $J=1.6,7.6,7.6$ and $14.6 \mathrm{~Hz}, 14-\mathrm{H}), 2.147(1 \mathrm{H}$, ddqd, $J=1.4,7.6,7.6$ and $14.6 \mathrm{~Hz}, 14-\mathrm{H}), 2.558(3 \mathrm{H}, \mathrm{s}, 7-$ $\left.\mathrm{NCOCH}_{3}\right), 3.332\left(3 \mathrm{H}, \mathrm{s}, 11-\mathrm{OCH}_{3}\right), 3.432\left(3 \mathrm{H}, \mathrm{s}, \mathrm{CH}_{3} \mathrm{O}-\right.$ of MTPA), $3.611\left(3 \mathrm{H}, \mathrm{s}, 8-\mathrm{OCH}_{3}\right), 4.497(1 \mathrm{H}, \mathrm{t}, J=9.0 \mathrm{~Hz}$, $11-\mathrm{H}), 5.250(1 \mathrm{H}$, tdd, $J=1.5,9.5$ and $11.0 \mathrm{~Hz}, 12-\mathrm{H})$, $5.539(1 \mathrm{H}, \mathrm{s}, 9-\mathrm{H}), 5.725(1 \mathrm{H}, \mathrm{d}, J=8.5 \mathrm{~Hz}, 10-\mathrm{H}), 5.823$ $(1 \mathrm{H}, \mathrm{td}, J=7.8$ and $11.0 \mathrm{~Hz}, 13-\mathrm{H}), 7.33 \sim 7.45(5 \mathrm{H}, \mathrm{m}$, $\mathrm{C}_{6} \mathrm{H}_{5^{-}}$of MTPA), $7.406(2 \mathrm{H}, \mathrm{t}, J=8.1 \mathrm{~Hz}, 20$ and $22-\mathrm{H})$, $7.517(1 \mathrm{H}, \mathrm{tt}, J=1.2$ and $7.3 \mathrm{~Hz}, 21-\mathrm{H}), 8.001(2 \mathrm{H}, \mathrm{dd}$, $J=1.2$ and $7.3 \mathrm{~Hz}, 19$ and $23-\mathrm{H}$ ).

6b: 'H NMR: $\delta 0.859(3 \mathrm{H}, \mathrm{t}, J=7.6 \mathrm{~Hz}, 15-\mathrm{H}), 1.762$ $(3 \mathrm{H}, \mathrm{s}, 16-\mathrm{H}), 2.023\left(3 \mathrm{H}, \mathrm{s}, 9-\mathrm{OCOCH}_{3}\right), 1.796(1 \mathrm{H}$, ddqd, $J=1.5,7.3,7.6$ and $14.6 \mathrm{~Hz}, 14-\mathrm{H}), 2.091(1 \mathrm{H}$, ddqd, $J=1.3,7.3,7.6$ and $14.6 \mathrm{~Hz}, 14-\mathrm{H}), 2.573(3 \mathrm{H}, \mathrm{s}, 7-$ $\left.\mathrm{NCOCH}_{3}\right), 3.304\left(3 \mathrm{H}, \mathrm{s}, 11-\mathrm{OCH}_{3}\right), 3.452\left(3 \mathrm{H}, \mathrm{s}, \mathrm{CH}_{3} \mathrm{O}-\right.$ of MTPA $), 3.612\left(3 \mathrm{H}, \mathrm{s}, 8-\mathrm{OCH}_{3}\right), 4.465(1 \mathrm{H}, \mathrm{t}, J=9.1 \mathrm{~Hz}$, $11-\mathrm{H}), 5.060(1 \mathrm{H}, \mathrm{tdd}, J=1.5,9.4$ and $11.0 \mathrm{~Hz}, 12-\mathrm{H})$, $5.554(1 \mathrm{H}, \mathrm{s}, 9-\mathrm{H}), 5.581(1 \mathrm{H}, \mathrm{td}, J=7.7$ and $11.0 \mathrm{~Hz}, 13-$ $\mathrm{H}), 5.635(1 \mathrm{H}, \mathrm{d}, J=8.8 \mathrm{~Hz}, 10-\mathrm{H}), 7.3 \sim 7.43(5 \mathrm{H}, \mathrm{m}$, $\mathrm{C}_{6} \mathrm{H}_{5^{-}}$of MTPA), $7.410(2 \mathrm{H}, \mathrm{t}, J=7.8 \mathrm{~Hz}, 20$ and $22-\mathrm{H})$, $7.524(1 \mathrm{H}, \mathrm{tt}, J=1.2$ and $7.3 \mathrm{~Hz}, 21-\mathrm{H}), 7.997(2 \mathrm{H}$, dd, $J=1.2$ and $7.3 \mathrm{~Hz}, 19$ and $23-\mathrm{H}$ ).

\section{References}

1) Ando, O.; H. Satake, M. Nakajima, A. Sato, T. Nakamura, T. Kinoshita, K. Furuya \& T. Haneishi: Synerazol, a new antifungal antibiotic. J. Antibiotics 44 : 382 389, 1991

2) Bloch, P. \& C. TAMm: Isolation and structure of pseurotin A, a microbial metabolite of Pseudeurotium ovalis STOLK with an unusual heterospirocyclic system. 
Helv. Chim. Acta 64: 304 315, 1981

3) Igarashi, Y; Y. Yabuta, A. Sekine, K. Fujil, K. Harada, T. Oikawa, M. Sato, T. Furumai \& T. Oki: Directed biosynthesis of fluorinated pseurotin A, synerazol and gliotoxin. J. Antibiotics, to submitted

4) Hayashi, Y.; M. Shojl, S. Yamaguchi, T. Mukaiyama, J.
YAmaguchi, H. KaKeYA \& H. Osada: Asymmetric total synthesis of pseurotin A. Org. Lett. 5: 2287 2290, 2003

5) Ohtani, I.; T. Kusumi, Y. Inouye, Y. Kashman \& H. KAKISAWA: High-field FT NMR application of Mosher's method. The absolute configurations of marine terpenoids. J. Am. Chem. Soc. 113: 4092 4096, 1991 